\title{
TAPARELLI CONTRA EL DIVORCIO
}

\author{
Mons. Jorge Hourton P.
}

El Padre Luis TAPARELLI d' Azeglio (1793-1862) es filósofo del derecho del siglo antepasado, italiano, fecundo escritor y polemista, autor de numerosas obras sobre el Derecho Natural y de ensayos doctrinales de filosofia política, luchador incansable contra autores liberales y racionalistas. servidor de la causa católica y pontificia en el tiempo anterior a la unificación italiana, muy sabio y erudito, autoridad reconocida en la teología social y política del diecinueve. Quise preguntarle qué enseña sobre la formación de leyes en un estado donde está presente el catolicismo.

Confesemos desde luego que Taparelli, visto ahora 140 años después de su muerte, es ultra conservador. Con decir que defiende a brazo partido la unión estrecha entre la Iglesia y el poder civil, defiende el poder del Papa sobre los Estados pontificios, amenazados por la casa de Saboya y denuncia como pésima y falsa la fórmula de Cavour "La Iglesia libre en un Estado libre" como vivió en los tiempos de auge del racionalismo kantiano, del liberalismo lockiano, del sensismo de Condillac y del utilitarismo de Benthan, se bate con vigor contra todas esas cabezas de hidra, férreamente armado con un escolastismo inflexible e inclemente.

Escribió una abundante producción, tanto tratados contundentes como articulos y opúsculos ocasionales, terciando en las arduas polémicas de su tiempo. No desmayó ni descansó nunca. No fue por fałta de empeño que sus enseñanzas no triunfaron, como no sea los grandes principios de la teología católica. Escribió, entre otras obras, un importante "SAGGIO TEORETICO DI DIRITTO NATURALE" ensayo original por la amplitud de sus temas, que cuenta más de 1200 páginas in quarto, reeditado y traducido muchas veces a varios idiomas. Hoy, a decir verdad, no es muy actual, aunque su estilo es claro y tiene carácter.

Por cierto Taparelli es contrario al divorcio vincular, que en ese siglo no ha alcanzado todavia mucha legislación civil. Pero como de hecho se practica con no poca frecuencia, Taparelli lo enfoca sólo como un acto contrario a la moral y al derecho natural. Por eso afirma la "indisolubilidad natural" del vinculo conyugal y por tanto el divorcio es objetivamente inmoral. Los argumentos que apoyan esta calificación se basan en un diagnóstico moral: el recurso al divorcio obedece a las pasiones y apetitos desordenados 
que impiden al hombre el recto ejercicio de sus libertad raconable por sobre su sensibilidad. Los obstáculos a la permanencia del vinculo legitimo podrian superarse. según el autor. por el buen uso razonable de la fuerza moral que el hombre tiene, a diferencia de las bestias que tienen sensibilidad pero no racionalidad y libertad. De todos modos, admite que las dificultades producidas por la variedad de pasiones y de temperamentos puedan "merecer alguna consideracion", pero "no doben cambiar las leyes que la razón deduce de las relaciones naturales ontre los casados y de los hechos del orden teorético y práctico". Pero agrega: "Fl legislador externo [positivo] de la sociedad debera tal vez tener on cuenta estas dificultades y usar de tolerancia" (N 1528).

\section{¿DE QUÉ TOLERANCIA PODRIA TRATARSE?}

Ya que nos dice que es el legislador quien debe usar de tolerancia, averigüemos qué puede competirle al legislador en esta materia.

Sorpresivamente nos encontramos con esta apreciación en el capitulo en que trata de "loyes morales del poder legislativo". Debe atenderse al fin de las leyes y a los sujetos sobre quienes se aplicarán. Atendiendo al fin, sigue el autor. debe cumplir dos condiciones: la justicia y la utilidad. Respecto a esta última nos dice:

"... las luyes deben ser apropiadas a los pueblos: y no solo en cuanto a la idea gencral de sociedad. smo un cuanto a sus condiciones individuantes Ahora bien. esas condiciones son doblemente mutables: mutables por el progreso qui puede tener la razón ordenadora: mutables por las circunstancias a las que quedan sujetos los individuos a ordenar. Si la razon ordonadora es perfectible, podra encontrar ordenamientos mojores: si el pucblo esta sujeto a mil circunstancias cambiantes. los mejores ordenamientos podran hacerse vanos y nocivos. Por lo tanto. si bien la ley es de suyo constante $y$ universal. clativamento a los individuos andará sujeta tanto a mutaciones como a excepciones. A mutación constante si otra ley aparece más conveniente a la sociedad: a excepciones si tha suspension aparece en algum momento mas convonicnto al individuo y a la suciedid" (N 1082 , las negritas pertenecen al texto de Taparelli: la traducción es nuestra).

\section{¿POR QUÉ HAY QUE EMPLEAR TOLERANCIA?}

Al exponer mas adelante otras condiciones morales para el establecimiento de leyes, atiende a lo que se requiere por parte de los sujetos. Nos dice que la ley no sólo debe ser fisicamente posible sino 
moralmente posible. $Y$ sigue una observación sobre los limites de las posibilidades morales de los sujetos:

“...no sería conveniente, no seria proporcionada a las presentes circunstancias de la sociedad, una ley cuya obediencia resultara moralmente imposible. Por eso es que bien puede. más aún debe. la ley humana tolerar muchos males". Y atiéndase a la razón que da: "...pues siendo moraimente imposible que la mayor parte de los seres humanos quieran vivir con perfección. la ley que prescribiera toda la perfección, pretende lo moralmente imposible."

"La prudencia del legislador consiste pues en conmensurar de modo tan certero las leyes a los medios sociales, que ella obtengan todo el bien moralmente posible, pero no manden nada del moralmente imposible. Y esta es la razón por la que hemos mostrado tan necesario al poder social un conocimiento recto y profundo del estado presente de una sociedad y para las leyes. cierto grado de mutabilidad, proporcionada a los cambios mismos de la sociedad" ( $N^{\text {"1095). }}$

Recojamos finalmente otro punto del Ensayo de Taparelli: al término del capitulo que hemos citado, añade una nota sabrosa que titula "EI soberano católico al pie del confesor". Tiene por objeto defender al eclesiástico de la acusación de que con su influencia sobre el gobernante se inmiscuye en asuntos especificamente politicos. Concluye con fineza: "un sabio confesor de principios no es un intrigante que quiere gobernar los reinos. pero un vocero que de parte de Dios llama a los gobernantes al tribunal de sus propias conciencias, les impone con autoridad el someterse a si mismos, regulando la cosa pública con las normas de sus propias razones, no obstante la queja de sus propios intereses y de sus propias pasiones" (Nota CIX).

Hay que reconocer que, todo lo anticuado que se quiera, este filósofo politico hace gala de un agudo sentido de la responsabilidad de gobernar y legislar con realismo al mismo tiempo a base de principios y de un exacto conocimiento de la realidad social y de los cambios culturales. Observo que no tiene una idea rigida y hierática (estoica) del Derecho Natural, sino, al modo de Tomás de Aquino, piensa que en el mundo humano, racional y libre, los gobernantes sabios y prudentes son la providencia del ordenamiento social. 